
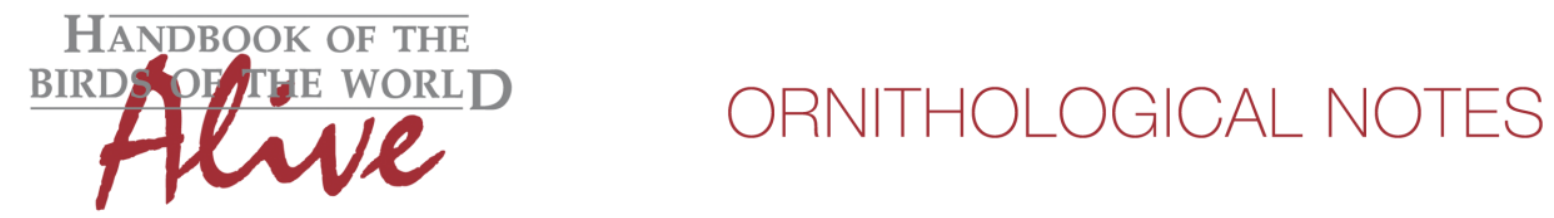

\title{
Notes on the vocalizations of Madagascar Brush-warbler (Nesillas typica)
}

Peter Boesman

In the following we briefly analyze and compare voice of the different races of Madagascar Brush-warbler (Nesillas typica). We also try to quantify the extent of any vocal differences using the criteria proposed by Tobias et al. (2010), as a support for taxonomic review.

We have made use of sound recordings available on-line from Xeno Canto (XC) and Macaulay Library (ML).

Song is said to be a series of melodic whistled notes (Pearson 2015), but elsewhere this is contradicted: there is apparently not a structured song, merely a series of 'calls' (Kennerley 2010). Indeed, all available recordings seem to be of a variety of 'check' calls and chatters (about 80 recordings from Madagascar and only 4 from Comores ( 2 moheliensis and 2 longicaudata)).

longicaudata is said to have rather higher-pitched calls, moheliensis being very similar (Kennerley 2010).

A few examples:

moheliensis

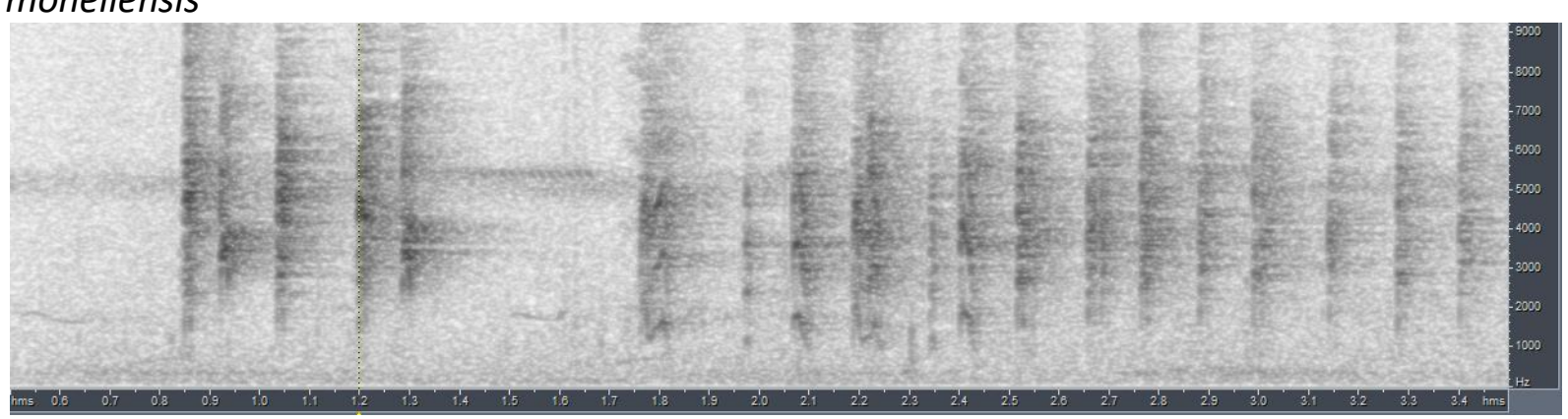

selected example of typica:

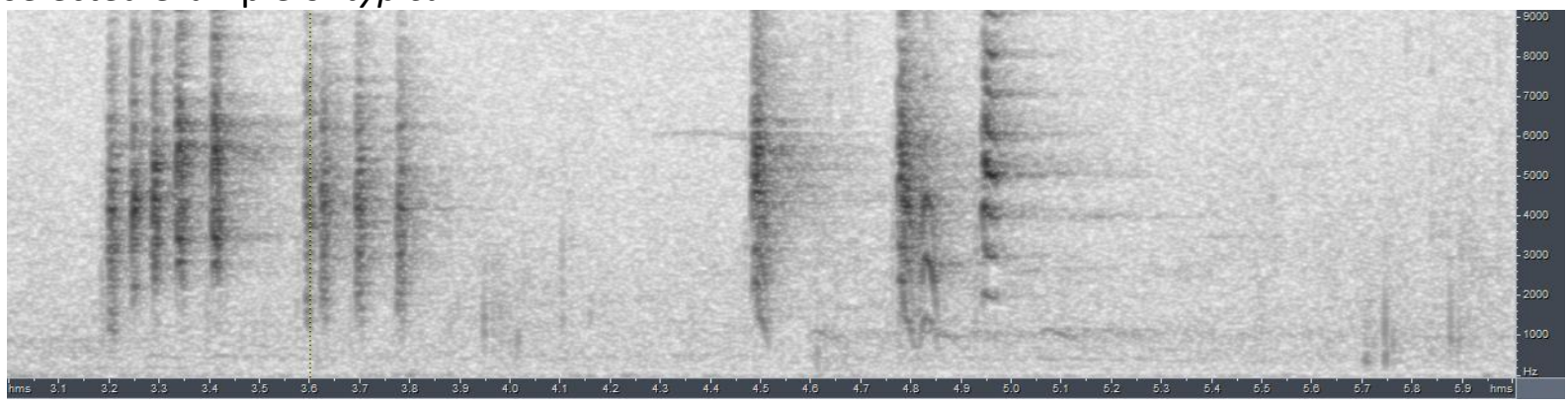

From the above sonograms it would seem that both frequencies and shapes of notes are very similar (!). 

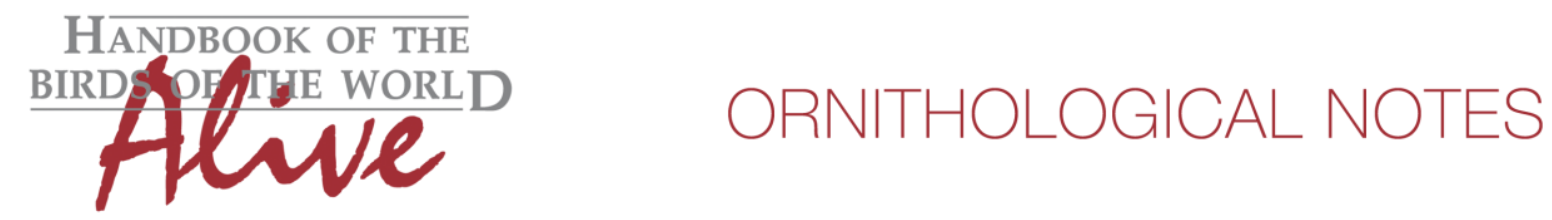

longicaudata rattle:

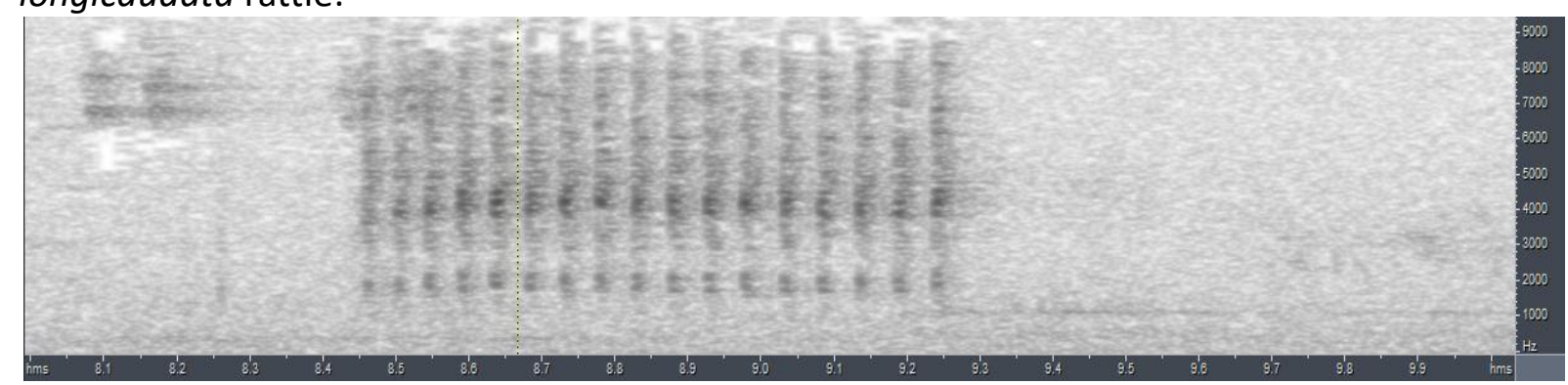

selected example of typica:

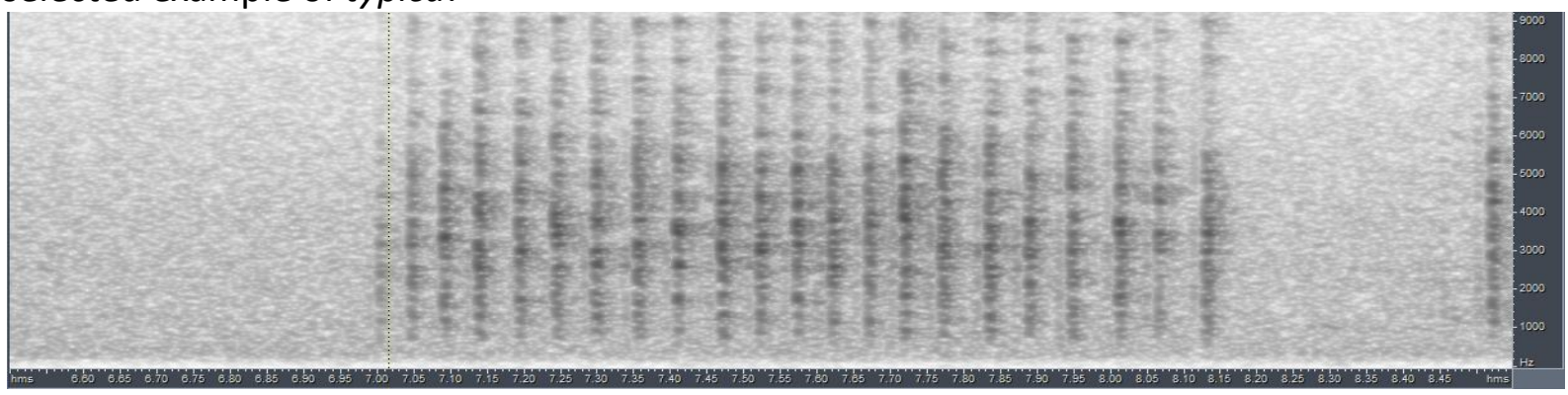

From the above sonograms, it would seem that pace and note length are very similar, fundamental frequency of longicaudata possibly is higher-pitched.

It would seem that many more good quality recordings of longicaudata and mohiliensis are needed to establish whether there are indeed consistent vocal differences among homologous vocalizations, or clear differences in vocabulary. Further study needed.

This note was finalized on 11th February 2016, using sound recordings available on-line at that moment. We would like to thank in particular the many sound recordists who placed their recordings for this species on $\mathrm{XC}$ and $\mathrm{ML}$.

\section{References}

Kennerley, P.R. \& Pearson, D. (2010). Reed and Bush Warblers. Helm Identification Guides. Christopher Helm, London.

Pearson, D. (2015). Madagascar Brush-warbler (Nesillas typica). In: del Hoyo, J., Elliott, A., Sargatal, J., Christie, D.A. \& de Juana, E. (eds.). Handbook of the Birds of the World Alive. Lynx Edicions, Barcelona. (retrieved from http://www.hbw.com/node/58776 on 11 February 2016).

Tobias, J.A., Seddon, N., Spottiswoode, C.N., Pilgrim, J.D., Fishpool, L.D.C. \& Collar, N.J. (2010). Quantitative criteria for species delimitation. Ibis 152(4): 724-746. 


\section{Recommended citation}

Boesman, P. (2016). Notes on the vocalizations of Madagascar Brush-warbler (Nesillas typica). HBW Alive Ornithological Note 232. In: Handbook of the Birds of the World Alive. Lynx Edicions, Barcelona. (retrieved from http://www.hbw.com/node/932195 on 29 September 2016). 